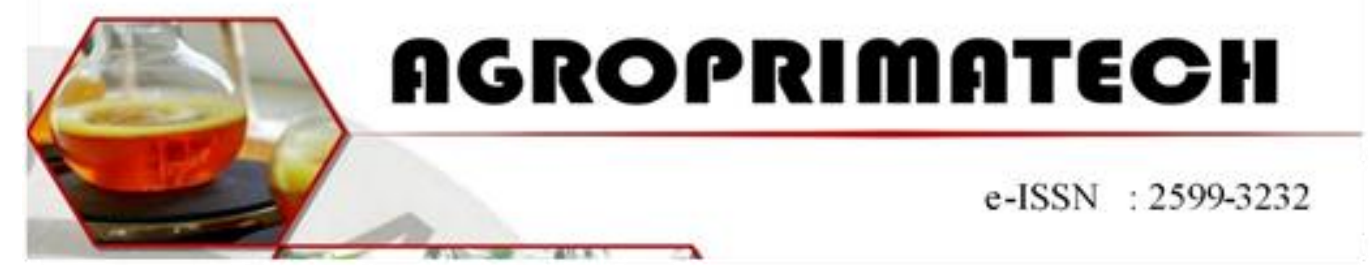

\title{
RESPON PERTUMBUHAN DAN PRODUKSI KUBIS (Brassica oleraceae.L) DENGAN PEMBERIAN BERBAGAI JENIS DAN DOSIS PUPUK KANDANG
}

\author{
ARVITA NETTI SIHALOHO ${ }^{1}$, ROSMADELINA PURBA ${ }^{2}$, YONTRA HALOHO ${ }^{3}$ \\ 1,2Dosen Fakultas Pertanian Prodi Agroteknologi, Universitas Simalungun \\ ${ }^{3}$ Mahasiswa Fakultas Pertanian Prodi Agroteknologi, Universitas Simalungun \\ Email: netti.haloho@gmail.com
}

\begin{abstract}
ABSTRAK
Penelitian ini dilaksanakan bertujuan untuk mendapatkan jenis dan dosis serta interaksi antara jenis dengan dosis pupuk kandang yang terbaik untuk pertumbuhan dan produksi tanaman kubis (Brassica oleraceae.L). Penelitian ini dilaksanakan di Tiga rungu Kabupaten Simalungun, dengan menggunakan Rancangan Acak Kelompok (RAK) Faktorial yang terdiri dari dua faktor yaitu: Faktor pertama pemberian jenis pupuk kandang yang terdiri dari 3 taraf yaitu J1 (pupuk kandang ayam), J2 (pupuk kandang sapi), J3 (Pupuk kandang kerbau). Faktor kedua dosis pupuk kandang yang terdiri dari 3 taraf yaitu: D1 (75g/tanaman), D2 (100g/tanaman), D3 (125 g/tanaman). Hasil penelitian menunjukkan bahwa perlakuan berbagai jenis dan dosis pupuk berpengaruh nyata terhadap semua parameter pengamatan, sedangkan interaksi antara jenis dan dosis pupuk kandang berpengaruh tidak nyata hanya pada pembentukan crop. Perlakuan pemberian pupuk kandang ayam dengan dosis $125 \mathrm{~g} / \mathrm{tanaman}$ menghasilkan kecepatan pembentukan crop tercepat $(45,67$ hari) berat kotor crop per tanaman sampel tertinggi $(3,55 \mathrm{~kg})$, berat bersih crop per tanaman sampel tertinggi $(2,47 \mathrm{~kg})$ berat kotor crop per plot $(3,46 \mathrm{~kg})$ dan berat bersih crop per plot $(2,72 \mathrm{~kg})$.
\end{abstract}

Kata Kunci: Crop, Produksi, Plot, Sampel, Nyata

\section{PENDAHULUAN}

Kol atau kubis merupakan tanaman sayur berupa tumbuhan berbatang lunak yang dikenal sejak jaman purbakala (25002000 SM) dan merupakan tanaman yang dipuja dan dimuliakan masyarakat Yunani Kuno. Kubis atau kol dengan nama latin (Brassica Oleracea) pada mulanya merupakan tumbuhan liar di daerah subtropik. Tanaman ini berasal dari daerah Eropa yang ditemukan pertama di Cyprus, Italia dan Mediteranian. Tanaman kubis termasuk dalam golongan tanaman sayuran semusim atau umur pendek. Tanaman kubis hanya dapat berproduksi satu kali setelah itu akan mati. Pemanenan kubis dilakukan pada saat umur kubis mencapai $60-80$ hari setelah tanam.

Kubis menjadi salah satu komoditas yang banyak dibudidayakan di Indonesia, terutama pada daerah dataran tinggi. Kubis sangat potensial untuk dikembangkan, karena selain untuk memenuhi kebutuhan dalam negeri, kubis juga berpotensi sebagai komoditas ekspor. Indonesia menjadi negara kelima terbesar dalam hal pemasok sayuran untuk Singapura setelah Malaysia, 
Cina, Australia dan India. Pada tahun 2009 volume ekspor untuk tanaman kubis mencapai 44.904 ton, paling besar dibandingkan dengan volume ekspor sayuran seperti jamur, bawang merah dan kentang. Jawa Tengah merupakan daerah penghasil kubis terbesar di Indonesia dibandingkan dengan propinsi lainnya (Kementerian Pertanian, 2015).

Pupuk adalah bahan yang ditambahkan ke dalam tanah untuk menyediakan unsur-unsur esensial bagi pertumbuhan tanaman. Penggolongan pupuk umumnya didasarkan pada sumber bahan yang digunakan, cara aplikasi, bentuk dan kandungan unsur haranya. Pemupukan memegang peranan penting dalam peningkatan produksi tanaman kubis, karena pupuk mengandung hara dengan kandungan tinggi. Pemupukan ini berfungsi untuk menyuburkan tanah (Wahida, 2011).

Pupuk kandang adalah pupuk yang berasal dari kandungan ternak, baik berupa kotoran padat (feses) yang berampur sisa makanan maupun air kencing. Pupuk kandang terdiri dari dua jenis padat dan cair. (Lestari dan Sihombing, 2014).

\section{METODE PENELITIAN}

Penelitian ini dilaksanakan di Purba Dolok, Kecamatan Purba, Kabupaten Simalungun dengan ketinggian $\pm 1.200 \mathrm{~m}$ diatas permukaan laut. Penelitian ini dilaksanakan selama tiga bulan, yang dimulai dari bulan November 2019 sampai bulan Januari 2020. Adapun bahan yang digunakan adalah: Pupuk NPK, pupuk kandang ayam, sapi dan kerbau Insektisida berbahan aktif Deltametrin, dan Fungisida berbahan aktif Propinep 70\%, benih kubis Varietas Erna F1 Green Nova, air. Alat yang digunakan adalah: Cangkul, gembor, meteran, gunting pangkas, timbangan, dan alat tulis dan alat-alat lainnya yang menunjang penelitian. Penelitian ini menggunakan Rancangan Acak Kelompok (RAK) 2 faktor. Faktor yang pertama adalah jenis pupuk kandang $(\mathrm{J})$ yang terdiri dari 3 taraf perlakuan yaitu: $J_{1}=$ kotoran ayam, $J_{2}$ $=$ kotoran sapi, $J_{3}=$ kotoran kerbau. Faktor kedua adalah dosis aplikasi pupuk kandang (D) yang terdiri dari 3 metode perlakuan yaitu: $D_{1}=75 \mathrm{gram} /$ pokok, $D_{2}=100 \mathrm{gram}$ / pokok dan $\mathrm{D}_{3}=125 \mathrm{gram} /$ pokok

Adapun parameter yang diamati antara lain Kecepatan Pembentukan Crop (hari), Berat Kotor Crop Per Tanaman Sampel (kg), Berat Bersih Crop Per Tanaman Sampel $(\mathrm{kg})$, Berat Kotor Crop Per Plot (kg) dan Berat Bersih Crop Per Plot (kg).

\section{HASIL DAN PEMBAHASAN}

Berdasarkan hasil analisa sidik ragam penelitian menunjukkan bahwa perlakuan berbagai jenis dan dosis pupuk kandang berpengaruh nyata terhadap semua parameter pengamatan. Interaksi perlakuan jenis dan dosis pupuk kandang berpengaruh tidak nyata hanya terhadap kecepatan pembentukan crop, sedangkan untuk parameter lainnya menunjukkan pengaruh nyata. Perbedaan masing masing perlakuan jenis dan dosis pupuk kandang terhadap kecepatan pembentukan crop, berat kotor crop per tanaman sampel, berat bersih crop pertanaman sampel, berat kotor crop per plot dan berat bersih crop per plot dapat dilihat pada Tabel 1.

Tabel 1. Uji Beda Rata Rata Pengaruh Perlakuan Berbagai Jenis dan Dosis Pupuk Kandang Terhadap Kecepatan Pembentukan Crop, Berat Kotor Crop Per Tanaman Sampel, Berat Bersih Crop Pertanaman Sampel, Berat Kotor Crop Per Plot dan Berat Bersih Crop Per Plot. 


\begin{tabular}{cccccc}
\hline Perlakuan & $\begin{array}{c}\text { Kecepatan } \\
\text { Pembentukan Crop } \\
\text { (Hari) }\end{array}$ & $\begin{array}{c}\text { Berat Kotor Crop } \\
\text { Per Tanaman } \\
\text { Sampel (Kg) }\end{array}$ & $\begin{array}{c}\text { Berat Bersih } \\
\text { Crop Per } \\
\text { Tanaman } \\
\text { Sampel (Kg) }\end{array}$ & $\begin{array}{c}\text { Berat Kotor } \\
\text { Crop Per } \\
\text { Plot (Kg) }\end{array}$ & $\begin{array}{c}\text { Berat } \\
\text { Bersih } \\
\text { Crop Per } \\
\text { Plot (Kg) }\end{array}$ \\
\hline J1 & $48.33 \mathrm{c}$ & $2.93 \mathrm{a}$ & $1,97 \mathrm{a}$ & $2.73 \mathrm{a}$ & $1.94 \mathrm{a}$ \\
J2 & $51.78 \mathrm{~b}$ & $2.56 \mathrm{~b}$ & $1,55 \mathrm{~b}$ & $2.52 \mathrm{~b}$ & $1.61 \mathrm{~b}$ \\
J3 & $56.33 \mathrm{a}$ & $1.90 \mathrm{c}$ & $1,24 \mathrm{c}$ & $2.13 \mathrm{c}$ & $1.23 \mathrm{c}$ \\
\hline D1 & $54.44 \mathrm{a}$ & $1.93 \mathrm{c}$ & $1,18 \mathrm{c}$ & $1.79 \mathrm{c}$ & $1.10 \mathrm{c}$ \\
$\mathrm{D} 2$ & $52.22 \mathrm{~b}$ & $2.36 \mathrm{~b}$ & $1,51 \mathrm{~b}$ & $2.44 \mathrm{~b}$ & $1.43 \mathrm{~b}$ \\
$\mathrm{D} 3$ & $49.78 \mathrm{c}$ & $3.11 \mathrm{a}$ & $2,08 \mathrm{a}$ & $3.17 \mathrm{a}$ & $2.25 \mathrm{a}$ \\
\hline J1D1 & 50.67 & $2.29 \mathrm{~g}$ & $1.44 \mathrm{e}$ & $1.83 \mathrm{~g}$ & $1.19 \mathrm{e}$ \\
J1d2 & 48.67 & $2.97 \mathrm{c}$ & $2.01 \mathrm{~b}$ & $2.91 \mathrm{~d}$ & $1.91 \mathrm{c}$ \\
J1D3 & 45.67 & $3.55 \mathrm{a}$ & $2.47 \mathrm{a}$ & $3.46 \mathrm{a}$ & $2.72 \mathrm{a}$ \\
J2D1 & 54.00 & $2.18 \mathrm{~h}$ & $1.19 \mathrm{f}$ & $2.06 \mathrm{f}$ & $1.13 \mathrm{e}$ \\
J2D2 & 51.33 & $2.53 \mathrm{f}$ & $1.51 \mathrm{~d}$ & $2.54 \mathrm{e}$ & $1.53 \mathrm{~d}$ \\
J2D3 & 50.00 & $2.98 \mathrm{~b}$ & $1.97 \mathrm{~b}$ & $2.98 \mathrm{c}$ & $2.18 \mathrm{~b}$ \\
J3D1 & 58.67 & $1.32 \mathrm{i}$ & $0.91 \mathrm{~h}$ & $1.48 \mathrm{i}$ & $0.98 \mathrm{f}$ \\
J3D2 & 56.67 & $1.57 \mathrm{e}$ & $1.02 \mathrm{~g}$ & $1.86 \mathrm{~h}$ & $0.87 \mathrm{~g}$ \\
J3D3 & 53.67 & $2.81 \mathrm{~d}$ & $1.79 \mathrm{c}$ & $3.07 \mathrm{~b}$ & $1.86 \mathrm{c}$ \\
\hline
\end{tabular}

Keterangan : Angka yang diikuti oleh huruf yang sama pada kolom yang sama dinyatakan berbeda tidak nyata pada uji BNT taraf $5 \%$

Tabel 1 memperlihatkan bahwa perlakuan yang paling cepat dalam pembentukan crop terdapat pada perlakuan $\mathrm{J} 1$ (48,33hari) yang berbeda nyata dengan J2 (51,78hari) dan J3 (56,33hari). Hal ini diduga karena pada perlakuan pupuk kandang ayam memiliki kandungan unsur hara yang lebih tinggi dibandingkan dengan pupuk kandang sapi dan pupuk kandang kerbau. Bila ketersediaan unsur hara yang lebih tinggi maka tanaman akan semakin cepat dalam proses pertumbuhan. Semakin baik pertumbuhan tanaman akan mempengaruhi tanaman pada proses pembentukan crop. Hal ini sesuai dengan pernyataan (Marliah et al., 2012), menyatakan kebutuhan hara makro dan mikro dalam jumlah optimal akan mendorong pertumbuhan dan hasil tanaman menjadi lebih baik.

Perlakuan dosis pupuk kandang menghasilkan kecepatan tumbuh tercepat pada perlakuan D3 ( 49,78 hari) yang berbeda nyata terhadap D1(54,44 hari) dan D2 (52,22 hari). Hal ini diduga karena pemberian pupuk kandang dengan dosis yang tinggi akan mempengaruhi pertumbuhan tanaman. Pemberian pupuk kandang dengan dosis yang tinggi akan menghasilkan unsur hara yang tinggi pula. Hal ini sesuai dengan pernyataan (Lubis et al., 2017), yang menyatakan bahwa secara fisik penambahan pupuk kandang mampu menciptakan kondisi tanah yang lebih baik bagi pertumbuhan tanaman, karena pupuk kandang dapat meningkatkan bahan organic tanah dan ketersediaan unsur hara, sehingga mendukung kecepatan tumbuh tanaman. Semakin baik pertumbuhan tanaman akan mempercepat pembentukan crop pada tanaman.

Interaksi perlakuan jenis pupuk kandang dan dosis pupuk kandang berpengaruh tidak nyata terhadap kecepatan pembentukan crop tanaman. Tetapi interaksi pupuk kandang dan dosis pupuk kandang menghasilkan kecepatan pembentukan crop tercepat terdapat pada perlakuan J1D3 (45,67 hari) dan yang paling lama terdapat pada perlakuan J3D1 (58,67 hari). Hal ini diduga karena pemberian pupuk kandang dengan dosis $125 \mathrm{~g}$ per tanaman akan menyediakan hara yang lebih banyak. Penambahan dosis pupuk kandang akan semakin baik terhadap pertumbuhan tanaman. Pupuk kandang juga dapat memperbaiki sifat fisik, kimia dan biologi tanah. Pemberian pupuk kandang akan menjaga microorganisme dalam tanah dan mampu menyediaakan kandungan air dalam tanah. Bila pertumbuhan tanaman semakin 
baik maka pembentukan crop juga akan semakin cepat.

Perlakuan jenis pupuk kandang terhadap berat kotor crop per tanaman sampel menunjukkan bahwa perlakuan J1 (pupuk Kandang Ayam) (2,93 kg) yang berbeda nyata terhadap perlakuan J2 (2,56 $\mathrm{kg})$ dan J3 (1,90 kg). Hal ini diduga Karena pupuk kandang ayam memiliki kandungan hara $\mathrm{N}, \mathrm{P}$ dan $\mathrm{K}$ yang lebih tinggi dibandingkan dengan pupuk kandang sapi dan kerbau. Selain itu pupuk kandang ayam juga lebih mudah terurai dibandingkan dengan pupuk kandang sapi dan kerbau. Hal ini sesuai dengan pernyataan Dan Winarto (2010) yang menyatakan bahwa pupuk kandang ayam mengandung nitrogen tiga kali lebih banyak dibanding pupuk kandang lainnya. Kandungan inilah yang dapat meningkatkan ningkatkan kesuburan tanah (Hartatik dan Widowati, 2006), sehingga akar lebih mudah menyerap unsur hara yang terkandung dalam tanah. Unsur hara yang terserap oleh akar akan digunakan oleh tanaman untuk meningkatkan pertumbuhan tanaman. Menurut Mayun (2007) pemberian pupuk kandang sebagai sumber pupuk organik mampu meningkatkan kandungan unsur hara, menetralkan $\mathrm{pH}$ tanah, mampu mengikat air dengan baik dalam tanah untuk menyediakan nutrisi untuk tanaman pada saat pertumbuhan tanaman. Sehingga dapat tumbuh dan berproduksi dengan baik.

Perlakuan dosis pupuk kandang menghasilkan berat kotor crop per tanaman sampel tertinggi pada perlakuan D3 $(3,17 \mathrm{~kg})$ yang berbeda nyata dengan perlakuan D1 $(1,79 \mathrm{~kg})$ dan perlakuan D2 $(2,43 \mathrm{~kg})$. Hal ini diduga karena pemberian pupuk kandang dengan dosis tinggi akan menghasilkan kadar hara N,P,K yang lebih tinggi pula.. Hal ini sesuai dengan pernyataan Menurut Marliah et al., (2012), suatu tanaman akan tumbuh dan berkembang dengan subur apabila unsur hara yang di butuhkan ada dan tersedia cukup serta ada dalam bentuk yang sesuai untuk di serap oleh bulu-bulu akar.

Interaksi perlakuan jenis pupuk kandang dan dosis pupuk kandang berbeda nyata menghasilkan interaksi tertinggi terdapat di JID3 $(3,55 \mathrm{~kg})$ dan yang terendah di J3D1 $(1,32 \mathrm{~kg})$. Hal ini diduga karena pupuk kandang ayam mengandung kadar hara yang lebih tinggi dari pada pupuk kandang sapi dan pupuk kandang kerbau. $\mathrm{Hal}$ ini sesuai dengan pernyataan Wijaya (2010) yang mengatakan bahwa penerapan pupuk kandang pada tanaman dengan dosis yang ditingkatkan mampu memenuhi kebutuhan unsur hara yang diantaranya adalah N, P dan K. Untuk melihat perbedaan berat kotor crop per tanaman sampel dapat

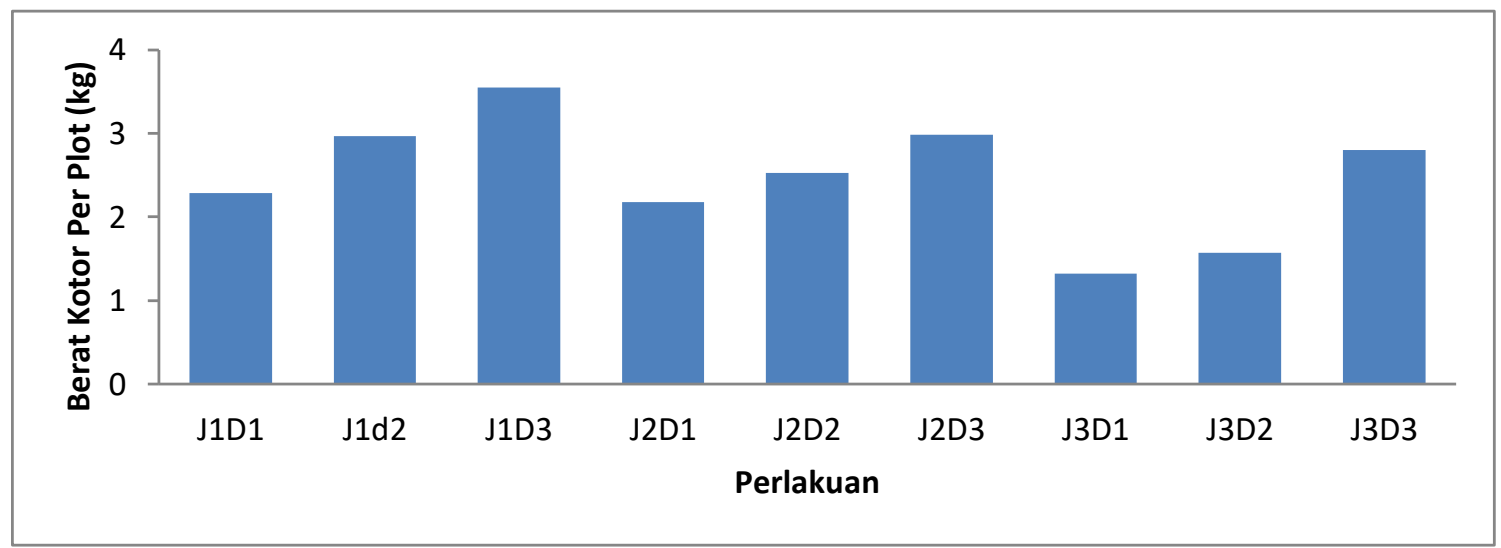

dilihat pada Gambar 1.

Gambar 1. Histogram Pengaruh Jenis Pupuk Kandang dan Dosis Pupuk Kandang Serta Interaksi Perlakuan Jenis Pupuk Kandang dan Dosis Pupuk Kandang Terhadap Berat Kotor Crop Per Tanaman Sampel $(\mathrm{kg})$

Hasil analisa perlakuan jenis pupuk kandang terdapat pada perlakuan $\mathrm{J} 1$
$(1,97 \mathrm{~kg})$ yang berbeda nyata dengan perlakuan J3 $(1,24 \mathrm{~kg})$ dan J2 (1,55 kg). Hal 
ini diduga karena pemberian pupuk kandang ayam (J1) mengandung kadar hara yang lebih tinggi dan lebih mudah terurai dibandingkan dengan pupuk kandang sapi dan pupuk kandang kerbau. Hal ini sesuai dengan pernyataan Wulandari dan Susanti (2012) yang menyatakan bahwa pengaplikasian pupuk organik pada tanaman sangat penting karena dapat menambah populasi jasad renik dan dapat menyuburkan tanah sehingga daya serap tanah terhadap air menjadi lebih baik. Mayun (2007) juga menyatakan bahwa pemberian pupuk kandang sebagai sumber pupuk organik mampu meningkatkan kandungan unsur hara pada tanah, mampu menetralkan $\mathrm{pH}$ tanah dan mempunyai daya mengikat air yang baik dalam tanah yang dibutuhkan tanaman untuk memperoleh nutrisi yang dibutuhkan tanaman.

Perlakuan dosis pupuk kandang menghasilkan berat bersih crop per tanaman sampel tertinggi terdapat pada perlakuan D3 $(2,08 \mathrm{~kg})$ yang berbeda nyata dengan perlakuan D1 $(1,18 \mathrm{~kg})$ namun berbeda tidak nyata dengan perlakuan D2 $(1,51 \mathrm{~kg})$. Hal ini sesuai dengan pernyataan (Simanullang, 2019) yang menyatakan bahwa dengan adanya pengoptimalan aplikasi pupuk kandang terhadap tanah dapat memberikan pengaruh positif terhadap sifat fisik, kimia dan biologi tanah, dapat mendorong perkembangan jasad renik dan menambah ketersediaan unsur hara yang dibutuhkan tanaman. Haryadi et al., (2015) menambahkan bahwa penambahan dosis pupuk kandang yang lebih banyak juga dapat mempengaruhi perkembangan akar tanaman sehingga nutrisi yang diserap tanaman optimal.

Interaksi perlakuan jenis pupuk kandang dan dosis pupuk kandang berbeda nyata menghasilkan interaksi tertinggi terdapat di JID3 $(2,47 \mathrm{~kg})$ namun berbeda tidak nyata terhadap J1D2 $(2,01 \mathrm{~kg})$ J2D3 $(1,97 \mathrm{~kg})$ dan yang terendah di J3D1 $(0,91$ $\mathrm{kg}$ ). Hal ini diduga semakin tercukupi kandungan hara yang dibutuhkan tanaman akan semakin baik pula pertumbuhan dan produksi tanaman yang dihasilkan. Hal ini sesuai dengan pernyataan Menurut Damanik, dkk (2011), penggunaan kandang yang tinggi akan kandungan nitrogen akam berpengaruh langsung terhadap sintetis karbohidrat didalam sel tanaman. Nitrogen juga berperan sebagai penyusun klorofil yang menyebabkan daun berwarna hijau dan menambah luas daun. Untuk melihat perbedaan masing masing berat bersih crop pertanaman sampel dapat dilihat pada Gambar 2.

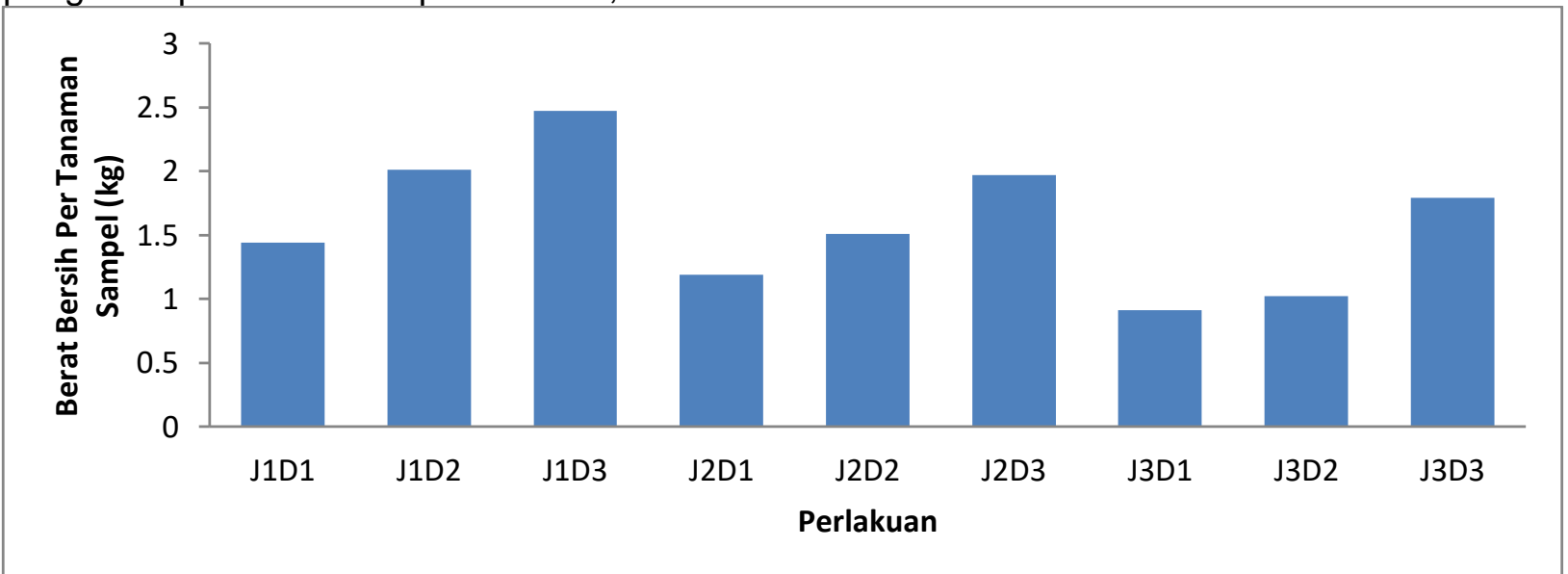

Gambar 2. Histogram Pengaruh Jenis Pupuk Kandang dan Dosis Pupuk Kandang dan Interaksi Perlakuan Jenis Pupuk Kandang dan Dosis Pupuk Kandang Terhadap Berat Bersih Crop Per Tanaman Sampel (kg)

Perlakuan jenis pupuk kandang berat kotor per plot terdapat pada perlakuan J1
$(2,73 \mathrm{~kg})$ yang berbeda nyata dengan perlakuan J2 $(2,52 \mathrm{~kg})$ dan J3 $(2,13 \mathrm{~kg})$. Hal 
ini diduga karena pupuk kandang ayam mengandung hara $\mathrm{N}, \mathrm{P}$ dan $\mathrm{K}$ yang lebih tinggi sehingga kebutuhan unsur hara lebih banyak didapat oleh tanaman tersebut. Pupuk kandang ayam juga lebih cepat terurai dalam tanah dibandingkan dengan pupuk kandang sapi dan pupuk kandang kerbau.sehingga unsurhara pada pupuk kandang tersebut lebih cepat tersedia pada tanaman. Hal ini sesuai dengan pernyataan Haryadi et al., (2015) yang menyatakan bahwa kandungan unsur hara $\mathrm{N}$ yang tinggi pada pupuk kandang ayam akan lebih mencukupi dibandingkan dengan pupuk kandang lainnya. Apabila kebutuhan unsur hara Nitrogen pada tanaman tercukupi maka akan mempengaruhi pertumbuhan tanaman menjadi lebih baik. Semakin baik pertumbuhan tanaman dapat mempengaruhi produksi yang dihasilkan tanaman tersebut.

Perlakuan dosis pupuk kandang menghasilkan berat kotor crop per plot tertinggi terdapat pada perlakuan D3 dengan berat $(3,17 \mathrm{~kg})$ yang berbeda nyata dengan perlakuan D1 $(1,79 \mathrm{~kg})$ dan D2 $(2,44 \mathrm{~kg})$. Hal ini diduga karena semakin tinggi dosis pupuk kandang yang diaplikasikan pada tanaman, maka akan semakin baik pula pertumbuhan dan produksi tanaman. Dosis pupuk kandang yang tinggi akan mengasilkan kadar unsur hara yang lebih tinggi untuk tanaman sehingga kebutuhan unsur hara yang didapatkan oleh tanaman lebih tercukupi. Hal ini sesuai dengan pernyataan Haryadi et al., (2015) yang menyatakan bahwa penerapan pupuk kandang dengan dosis yang ditingkatkan mampu memenuhi unsur hara pada tanaman terutama unsur $\mathrm{N}$. Interaksi perlakuan jenis pupuk kandang dan dosis pupuk kandang menghasilkan berat kotor crop per plot tertinggi terdapat pada perlakuan J1D3 $(3,46$ $\mathrm{kg})$ dan yang terendah J3D1 $(0,91 \mathrm{~kg})$. Hal ini diduga karena semakin tinggi dosis pupuk kandang yang diaplikasikan akan semakin baik pula perkembangan dan produksi tanaman yang dihasilkan. Pupuk kandang ayam memiliki kandungan unsur hara yang lebih tinggi dibandingkan dengan pupuk kandang sapi dan pupuk kandang kerbau. Pupuk kandang ayam juga lebih mudah larut dibandingkan dengan pupuk kandang sapi dan pupuk kandang kerbau. Semakin cepat pupuk kandang terdekomposisi atau larut dalam tanah maka akan semakin cepat pula tanaman mendapatkan unsur hara dalam pupuk kandang tersebut.Untuk melihat perbedaan masing masing berat kotor crop per plot dapat dilihat pada Gambar 3.

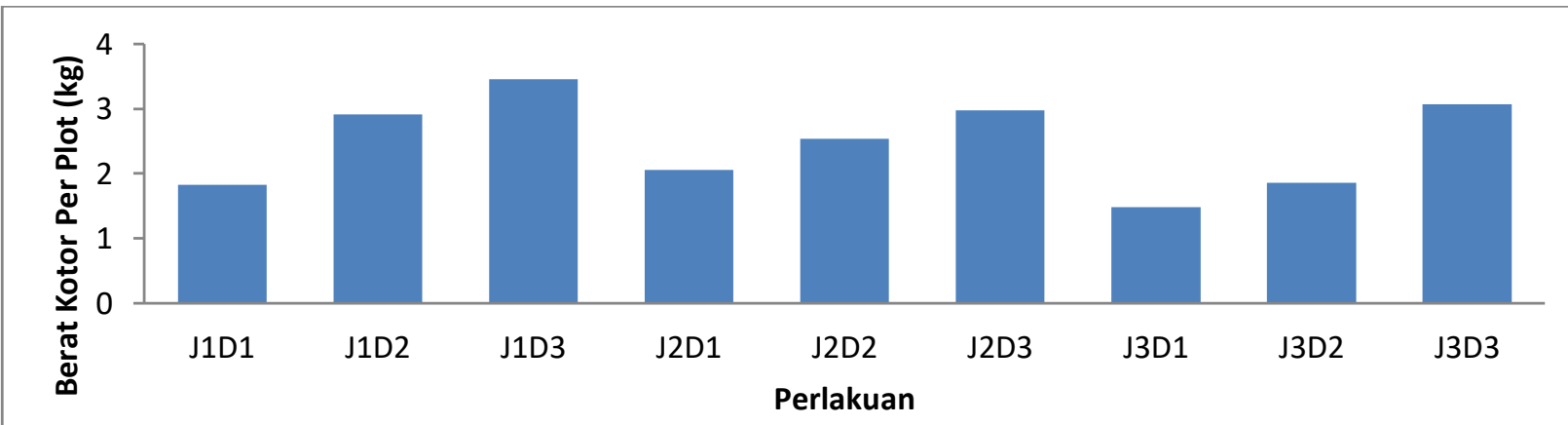

Gambar 3. Histogram Pengaruh Jenis Pupuk Kandang dan Dosis Pupuk Kandang dan Interaksi Perlakuan Jenis Pupuk Kandang dan Dosis Pupuk Kandang Terhadap Berat Kotor Crop Per Plot (kg)

Perlakuan jenis pupuk kandang terdapat pada $\mathrm{J} 1(1,94 \mathrm{~kg})$ yang berbeda nyata dengan perlakuan $\mathrm{J} 2(1,61 \mathrm{~kg})$ dan $\mathrm{J} 3$ $(1,23 \mathrm{~kg})$. Hal ini diduga karena pupuk kandang ayam memiliki kandangan unsur hara yang lebih tinggi dibandingkan dengan pupuk kandang lainnya. Pupuk kandang ayam juga lebih mudah terurai dalam tanah, sehingga unsur hara pada pupuk kandang tersebut lebih cepat tersedia untuk tanaman. Hal ini sesuai dengan pernyataan Damanik dkk (2011) menyatakan bahwa pupuk 
kandang ayam memiliki kandungan hara Nitrogen yang lenih banyak dari pada pupuk kandang lainnya. Unsur hara ini sangat diperukan tanaman pada masa perumbuhan.

Perlakuan dosis pupuk kandang menghasilkan berat bersih crop per plot tertinggi terdapat pada perlakuan D3 $(2,25$ $\mathrm{kg})$ yang berbeda nyata dengan D1 $(1,10 \mathrm{~kg})$ dan D2 ( 1,43 kg). Hal ini diduga karena semakin tinggi dosis yang diaplikasikan maka, semakin tinggi pula unsur hara yang didapatkan olrh tanaman. Hal ini sesuai dengan pernyataan Kusuma (2012) menyatakan bahwa pemberian pupuk kandang dengan dosis yang tinggi akan mempengaruhi pertumbuhan dan produksi tanaman.

Interaksi perlakuan jenis pupuk kandang dan dosis pupuk kandang menghasilkan berat bersih crop per plot tertinggi pada perlakuan dosis pupuk kandang terdapat pada perlakuan. JID3 $(2,72 \mathrm{~kg})$ namun berbeda tidak nyata terhadap J1D2 (1,91 kg), J3D3 (1,86 kg) J1D1 $(1,19 \mathrm{~kg})$ dan J2D1 $(1,13 \mathrm{~kg})$. Hal ini diduga karena pemberian pupuk kandang dengan dosis yang tinggi akan menyediakan unsur hara yang lebih tinggi untuk tanaman sehingga pada proses pertumbuhan, kebutuhan unsur hara tercukupi untuk tanaman.

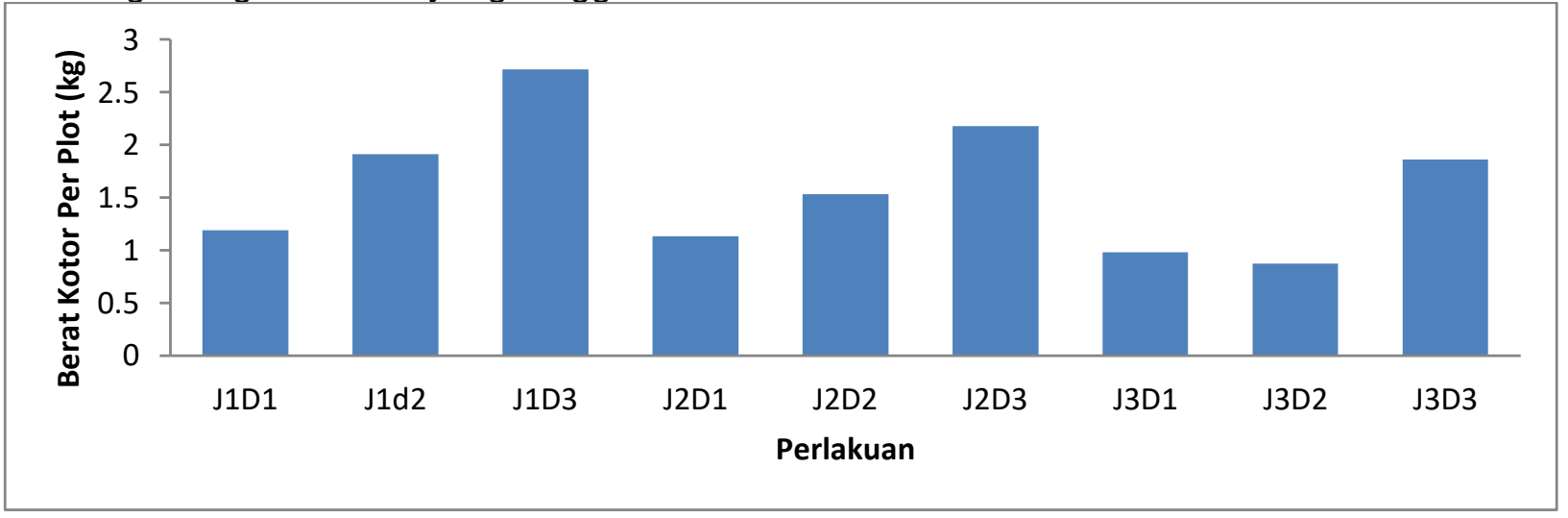

Gambar 4. Histogram Pengaruh Perlakuan Jenis Pupuk Kandang dan Dosis Pupuk Kandang dan Interaksi Perlakuan Jenis Pupuk Kandang dan Dosis Pupuk Kandang Terhadap Berat Bersih Crop Per Plot $(\mathrm{kg})$

Hal ini sesuai dengan pernyataan Menurut Lestari dan Sihombing, (2014), yang menyatakan bahwa suatu tanaman akan tumbuh dan berkembang dengan subur apabila unsur hara yang di butuhkan ada dan tersedia cukup serta ada dalam bentuk yang sesuai untuk di serap oleh bulu-bulu akar. Respon tanaman terhadap pemberian pupuk akan meningkat bila menggunakan jenis pupuk, dosis, waktu dan cara pemberian yang tepat. Untuk melihat perbedaan masing masing berat bersih crop per plot dapat dilihat pada Gambar 4.

\section{KESIMPULAN}

1. Perlakuan berbagai jenis pupuk berpengaruh nyata terhadap semua parameter pengamatan. Perlakuan pupuk kandang ayam menghasilkan pembentukan crop tercepat (48,33 hari), berat kotor crop per tanaman sampel tertinggi $(2,93 \mathrm{~kg})$, berat bersih crop per tanaman sampel tertinggi $(1,97 \mathrm{~kg})$ berat kotor crop per plot $(2,73 \mathrm{~kg})$ dan berat bersih crop per plot $(1,94 \mathrm{~kg})$.

2. Perlakuan berbagai dosis pupuk kandang berpengaruh nyata terhadap semua parameter pengamatan. Perlakuan berbagai dosis pupuk kandang dengan dosis $125 \mathrm{~g} /$ tanaman menghasilkan pembentukan crop tercepat $(49,78$ hari), berat kotor crop per tanaman sampel tertinggi $(3,11 \mathrm{~kg})$, berat bersih crop per tanaman sampel tertinggi $(2,08 \mathrm{~kg})$ berat 
kotor crop per plot $(3,17 \mathrm{~kg})$ dan berat bersih crop per plot $(2,25 \mathrm{~kg})$.

3. Interaksi perlakuan berbagai jenis dan dosis pupuk kandang berpengaruh tidak nyata terhadap kecepatan pembentukan crop,namun berbeda nyata terhadap parameter pengamatan lainnya. Perlakuan pemberian pupuk kandang ayam dengan dosis 125g/tanaman menghasilkan kecepatan pembentukan crop tercepat $(45,67$ hari) berat kotor crop per tanaman sampel tertinggi $(3,55 \mathrm{~kg})$, berat bersih crop per tanaman sampel tertinggi $(2,47 \mathrm{~kg})$ berat kotor crop per plot $(3,46 \mathrm{~kg})$ dan berat bersih crop per plot $(2,72 \mathrm{~kg})$

\section{DAFTAR PUSTAKA}

Ahmad Ridwan Lubis, Lisa Mawarni, R. S. (2017). View of Respon Pertumbuhan Bibit Kopi Robusta (Coffea robusta L (pp. 692-696). urnal Agroekoteknologi FP USU.

Arum Sekar Wulandari, Sri Susanti. (2012). Aplikasi Pupuk Daun Organik Untuk Meningkatkan Pertumbuhan Bibit Jabon (Anthocephalus cadamba Roxb. Miq.). Jurnal Silvikultur Tropika, Vol. 03 No(ISSN: 2086-8227), Hal. 137 - 142.

Napitupulu, D., Winarto, (2010). Pengaruh Pemberian Pupuk $N$ dan K terhadap Pertumbuhan dan Produksi Bawang Merah. Jurnal Hortikultura, Vol.20(1): 27-35.

Dede Haryadi, Husna Yetti, S. Y. (2015). Pengaruh Pemberian Beberapa Jenis Pupuk Terhadap Pertumbuhan dan Produksi Tanaman Kailan (Brassica alboglabra L.). Jom Faperta, 2(2).
Hartatik, W. Widowati, L. . (2006). 4. Pupuk Kandang. Pupuk Organik Dan Pupuk Hayati, 59-82.

Ida Ayu Mayun. (2007). Efek Mulsa Jerami Padi dan Pupuk Kandang Sapi terhadap Pertumbuhan dan Hasil Bawang Merah di Daerah Pesisir.

Kementerian Pertanian. (2015). Statistik Produksi Hortikultura Tahun 2014. Kementerian Pertanian Direktorat Jenderal Hortikultura.

Marliah, A., Hayati, M., Muliansyah, I. (2012). Pemanfaatan Pupuk Organik Cair Terhadap Pertumbuhan Dan Hasil Beberapa Varietas Tomat (Lycopersicum Esculentum L.). Jurnal Agrista, 16(3), 122-128.

Simanullang, A. Y. (2019). Pengaruh Pupuk Organik Dan Anorganik Terhadap Pertumbuhan Dan Hasil Tanaman Sawi Hijau ( Brassica rapa L.) (p. 15).

Wahida, N. R. S, H. H. (2011). Aplikasi Pupuk Kandang Ayam Pada Tiga Varietas Sorgum (Sorghum Bicolor L. Moench) Application of chicken manure on the three varieties of Sorghum (sorghum bicolor L. Moench).

Widya Lestari dan Roi Hendra Sihombing. (2014). Pengaruh Effective Mikroorganisme (Em4) Pada Bokasi Dan Waktu Aplikasi Bokasi Terhadap Pertumbuhan Dan Produksi Tanaman Selada ( Lactuca sativa ) Widya Lestari dan Roi Hendra Sihombing. Jurnal Agroplasma (STIPER) Labuhanbatu, 1(1), 22-29. 